\title{
Small mammal diversity in Semi-deciduous Seasonal Forest of the southernmost Brazilian Pampa: the importance of owl pellets for rapid inventories in human-changing ecosystems
}

\author{
Narla Shannay Stutz'; Patrícia Hadler'; Jorge José Cherem ${ }^{3}$ \& Ulyses Francisco José Pardiñas ${ }^{4,5}$ \\ 1 Universidade Federal do Rio Grande do Sul (UFRGS), Instituto de Geociências (IGE0), Programa de Pós Graduação em Geociências (PPGGE0). \\ Porto Alegre, RS, Brasil. ORCID: http://orcid.org/0000-0002-1937-3902. E-mail: narla_stutz@yahoo.com.br (corresponding author) \\ 2 Universidade Federal de Santa Catarina (UFSC), Departamento de Geologia (DGL), Laboratório de Paleontologia (LABPALEO), \\ Programa de Pós-Graduação em Geologia. Florianópolis, SC, Brasil. ORCID: http://orcid.org/0000-0003-4897-3111. E-mail: patricia.hadler@ufsc.br \\ ${ }^{3}$ Caipora Cooperativa para a Conservação da Natureza. Florianópolis, SC, Brasil. ORCID: http://orcid.org/0000-0001-9718-9628. \\ E-mail: jjcherem@gmail.com \\ ${ }^{4}$ Instituto de Diversidad y Evolución Austral (IDEAUS) y Consejo Nacional de Investigaciones Científicas y Técnicas (CONICET). \\ Puerto Madryn, Chubut, Argentina. ORCID: http://orcid.org/0000-0001-9496-5433. E-mail: ulyses@cenpat-conicet.gob.ar \\ ${ }^{5}$ Instituto Nacional de Biodiversidad (INABI0). Quito, Pichincha, Ecuador.
}

\begin{abstract}
The Pampa biogeographic province covers a mere $2 \%$ of the Brazilian territory $\left(176,496 \mathrm{~km}^{2}\right)$. However, it stands out as a complex and diverse ecosystem, although its mammal communities are still scarcely understood. Human activities are transforming the territory into a mosaic of agroecosystems, native and exotic forest fragments, and grasslands. Here we conducted the first investigation to determine the richness of small mammal assemblages in the region based on extensive analyses of owl pellets (Tyto furcata). Craniodental remains were studied from samples collected from 12 Semi-deciduous Seasonal Forest sites in the municipality of São Lourenço do Sul, State of Rio Grande do Sul, Southern Brazil. A total of 2,617 individuals belonging to 18 taxa were recorded, including 2 marsupials (Didelphidae; 0.42\%), 2 chiropterans (Molossidae, Phyllostomidae; 0.12\%), and 14 rodents (Cricetidae, Muridae, Caviidae; 99.46\%). The rodent genera Oligoryzomys, Mus, Calomys, and Akodon were the most common taxa. Large samples also included poorly known taxa, such as the cricetids Bibimys, Juliomys (recording here its southernmost occurrence), Lundomys, and Wilfredomys. From a biogeographical point of view, the recorded assemblage embraces a mixture of Platan, Pampean, and Atlantic Forest elements, highlighting the role of the southernmost Brazilian hills as a wedge favoring the penetration of forest micromammals to higher latitudes. Our findings testify to the great diversity of the Pampa, but also point to a growing homogeneity and dominance of rodent species that are widespread in agroecosystems. Rapid inventories based on owl pellets emerge as a suitable, economic, non-invasive tool to document these community changes.
\end{abstract}

Key-Words. Bibimys; Juliomys; Lundomys; Tyto furcata; Wilfredomys.

\section{INTRODUCTION}

The Pampa biogeographic province extends from the southern half of the State of Rio Grande do Sul (RS, hereafter) in Brazil across the whole of Uruguay to Central Argentina (Morrone, 2001). In Brazil, the Pampa is one of the smallest biomes, covering an area of $176,496 \mathrm{~km}^{2}$, which corresponds to $2.07 \%$ of the national territory (IBGE, 2004a). Although dominated by grasslands and largely treated as a non-forest ecosystem (Overbeck et al., 2015), the Brazilian Pampa also encompasses the southernmost expression of Semi-deciduous Seasonal Forest (Belton, 1984). The latter is ar- ranged into two blocks: The larger Southern Block $\left(10,137.73 \mathrm{~km}^{2}\right)$ is located on the eastern slope of the Serra do Sudeste, flanking the Patos lagoon, and the Northern Block $\left(3,159.03 \mathrm{~km}^{2}\right)$ is located on the southeastern Meridional Plateau. These forest environments have been almost totally converted to agroecosystems (IBGE, 2004b; Cordeiro \& Hasenack, 2009). Today, the general landscape is constituted by myriad small patches of native and exotic forests and cleared areas supporting pastures or grasslands (Cordeiro \& Hasenack, 2009). The few, but important, efforts directed at exploring the non-volant small mammals in these grassland-forest ecotones have revealed diverse 
communities of rodents and marsupials, while also finding disturbed habitats harbor simplified species assemblages (Luza et al., 2016).

The analysis of owl pellet samples has been considered a useful tool to inventory small mammals (e.g., Taylor, 1994; Bonvicino \& Bezerra, 2003; Torre et al., 2004; Pardiñas et al., 2005; Teta et al., 2010; Meek et al., 2012; Baglan \& Catzeflis, 2016; Mancini et al., 2018). In addition, it is a relatively easy and low-cost method that generates estimates of species richness that are identical or higher than those obtained by expensive traditional methods (e.g., trapping; Torre et al., 2004). Indeed, the fauna contained in owl pellets has been considered a better representation of the composition of small mammal communities on a broader spatiotemporal scale (Formoso et al., 2016; Heisler et al., 2016). In southern Brazil, few studies have utilized Tyto furcata (Temminck, 1827) pellets. Nonetheless, the potential of the pellets to record small mammal communities has been corroborated by the variety of species recorded and the reports of rare taxa (e.g., González et al., 1999; Scheibler \& Christoff, 2007; Peters et al., 2010; Cherem et al., 2018).

Here, we studied a large sample of cranial and mandibular fragments of small mammals derived from Tyto furcata pellets representing Semi-deciduous Seasonal Forest faunas in the southern Pampa Biome. Our survey focused on the municipality of São Lourenço do Sul in RS, Brazil. This administrative unit is of particular relevance because it encompasses several mammal type-localities (e.g., Wilfredomys oenax (Thomas, 1928), Lutreolina crassicaudata lutrilla Thomas, 1923, Lasiurus enslenii Lima, 1926) (Avila-Pires, 1994). In addition, it represents the southernmost expression of forest elements and, as such, the potential limit between the Brazilian and Patagonian mammalian subregions (Hershkovitz, 1958). Our aim is thus to contribute to the knowledge of current Pampa small mammal assemblages, including the record of poorly known taxa. In addition, we emphasize the necessity to conduct extensive and low-cost surveys as a way to explore small mammal assemblages in rapidly changing anthropogenic environments.

\section{MATERIAL AND METHODS}

The municipality of São Lourenço do Sul (SLS, hereafter) is located on the eastern slope of the Serra do Sudeste, near the coastal region of RS (Brazil). The climate is mild mesothermal, with average temperatures between 10 and $15^{\circ} \mathrm{C}$, super humid, and without periods of drought (IBGE, 1978). On the $2^{\text {nd }}$ and $3^{\text {rd }}$ July 2018 , owl pellet samples were collected from inside buildings (sheds, churches, and abandoned houses) that were used as shelters by the owl Tyto furcata, totaling 12 sampling sites in SLS (Fig. 1). The sites are located at altitudes of between 70 and $280 \mathrm{~m}$ and are within the phytoeco-

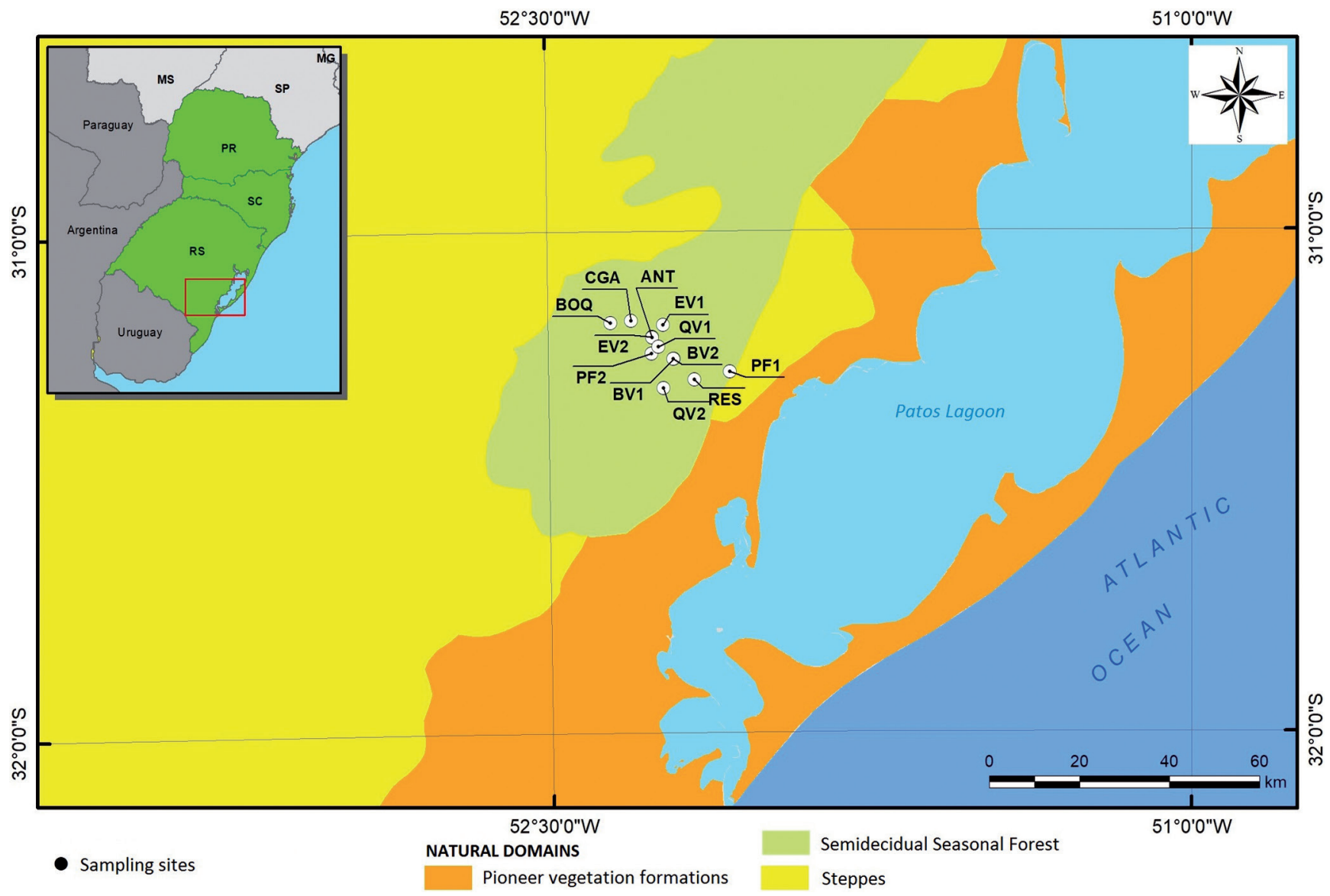

Figure 1. Location of the sampling sites of the Tyto furcata pellets at the Municipality of São Lourenço do Sul, State of Rio Grande do Sul, Southern Brazil. BV1 = Boa Vista I; BV2 = Boa Vista II; BOQ = Boqueirão; CGA = Canta Galo; EV1 = Evaristo I; EV2 = Evaristo II; ANT = Picada das Antas; PF1 = Picada Feliz l;PF2 = Picada Feliz II; QV1 = Quevedos I; QV2 = Quevedos II; RES = Reserva. Map modified from MMA (1992). 
Table 1. Sampling sites of Tyto furcata pellets at the municipality of São Lourenço do Sul, State of Rio Grande do Sul, Southern Brazil. UFSC-CF = Coleção de Fragmentos Ósseos do Laboratório de Paleontologia, Universidade Federal de Santa Catarina.

\begin{tabular}{|c|c|c|c|}
\hline Sampling Site & Abbreviation & Coordinates (WGS 84) & Catalog number \\
\hline Boa Vista I & BV1 & $31^{\circ} 15^{\prime} 17^{\prime \prime} \mathrm{S}, 52^{\circ} 12^{\prime} 31^{\prime \prime} \mathrm{W}$ & UFSC-CF 38 \\
\hline Boa Vista II & BV2 & $31^{\circ} 15^{\prime} 18^{\prime \prime} \mathrm{S}, 52^{\circ} 12^{\prime} 34^{\prime \prime} \mathrm{W}$ & UFSC-CF 39 \\
\hline Boqueirão & BOQ & $31^{\circ} 16^{\prime} 55^{\prime \prime} \mathrm{S}, 52^{\circ} 04^{\prime} 39^{\prime \prime} \mathrm{W}$ & UFSC-CF 35 \\
\hline Canta Galo & CGA & $31^{\circ} 10^{\prime} 58^{\prime \prime} \mathrm{S}, 52^{\circ} 21^{\prime} 19^{\prime \prime} \mathrm{W}$ & UFSC-CF 41 \\
\hline Evaristo I & EV1 & $31^{\circ} 11^{\prime} 13^{\prime \prime} \mathrm{S}, 52^{\circ} 13^{\prime} 58^{\prime \prime} \mathrm{W}$ & UFSC-CF 40 \\
\hline Evaristo II & EV2 & $31^{\circ} 10^{\prime} 43^{\prime \prime} \mathrm{S}, 52^{\circ} 18^{\prime} 25^{\prime \prime} \mathrm{W}$ & UFSC-CF 42 \\
\hline Picada das Antas & ANT & $31^{\circ} 18^{\prime} 48^{\prime \prime} \mathrm{S}, 52^{\circ} 13^{\prime} 58^{\prime \prime} \mathrm{W}$ & UFSC-CF 37 \\
\hline Picada Feliz I & PF1 & $31^{\circ} 12^{\prime} 39^{\prime \prime} \mathrm{S}, 52^{\circ} 15^{\prime} 29^{\prime \prime} \mathrm{W}$ & UFSC-CF 32 \\
\hline Picada Feliz II & PF2 & $31^{\circ} 12^{\prime} 46^{\prime \prime S}, 52^{\circ} 15^{\prime} 29^{\prime \prime} \mathrm{W}$ & UFSC-CF 33 \\
\hline Quevedos I & QV1 & $31^{\circ} 14^{\prime} 41^{\prime \prime} \mathrm{S}, 52^{\circ} 15^{\prime} 35^{\prime \prime} \mathrm{W}$ & UFSC-CF 34 \\
\hline Quevedos II & QV2 & $31^{\circ} 13^{\prime} 51^{\prime \prime} \mathrm{S}, 52^{\circ} 14^{\prime} 37^{\prime \prime} \mathrm{W}$ & UFSC-CF 43 \\
\hline Reserva & RES & $31^{\circ} 17^{\prime} 47^{\prime \prime} S, 52^{\circ} 09^{\prime} 38^{\prime \prime} \mathrm{W}$ & UFSC-CF 36 \\
\hline
\end{tabular}

logical region of Semi-deciduous Seasonal Forest, Pampa Biome (Leite, 2002).

The owl pellet preparation included maceration in hot water with $\mathrm{NaClO} 2 \%$ (3 ml per liter of water) over 24 hours, followed by washing with running water to remove bristles and then handpicking of the bones. The craniodental material was deposited in the Coleção de Fragmentos Ósseos do Laboratório de Paleontologia, Universidade Federal de Santa Catarina, Florianópolis (UFSC-CF), State of Santa Catarina, Brazil (Table 1). The taxonomic identification of the small mammals was made by comparison with specimens deposited in the Coleção de Mamíferos do Departamento de Ecologia e Zoologia, Universidade Federal de Santa Catarina, Florianópolis (UFSC) (see Appendix 1) and specific literature (Barquez et al., 1999; Gonçalves et al., 2007; Patton et al., 2015; Hadler et al., 2016; Stutz et al., 2017, 2018; Cherem et al., 2018). The taxonomy employed here follows Gardner (2008) for Didelphimorphia and Chiroptera, Wilson \& Reeder (2005) for Muridae, and Patton et al. (2015) for the other rodents; taxonomic ordination follows Wilson \& Reeder (2005). Threatened species at global (IUCN, 2019), national (ICMBio, 2018), and state (Rio Grande do Sul, 2014) levels are indicated, as are exotic invasive species (Rio Grande do Sul, 2013). The minimum number of individuals (MNI) per species and per sampling site was determined by considering the greatest number of right or left mandibles or maxillaries (Beisaw, 2013). The length of the upper molar series (LM1-M3) of the sigmodontine rodents was measured with a manual caliper with a precision of $0.02 \mathrm{~mm}$. Molar abbreviations are: M1, first upper molar; $\mathrm{m} 1$, first lower molar; $\mathrm{M} 2$, second upper molar; $\mathrm{m} 2$, second lower molar; M3, third upper molar; m3, third lower molar.

\section{RESULTS}

The Tyto furcata pellets from 12 sites in SLS contained 2,617 individuals belonging to 19 small mammal taxa, including two didelphimorphian species
(Didelphidae) (Fig. 2), two chiropterans (Molossidae and Phyllostomidae) (Fig. 3), and 15 rodents (Cricetidae, Muridae, and Caviidae) (Figs. 4, 5, and 6) (Table 2). The
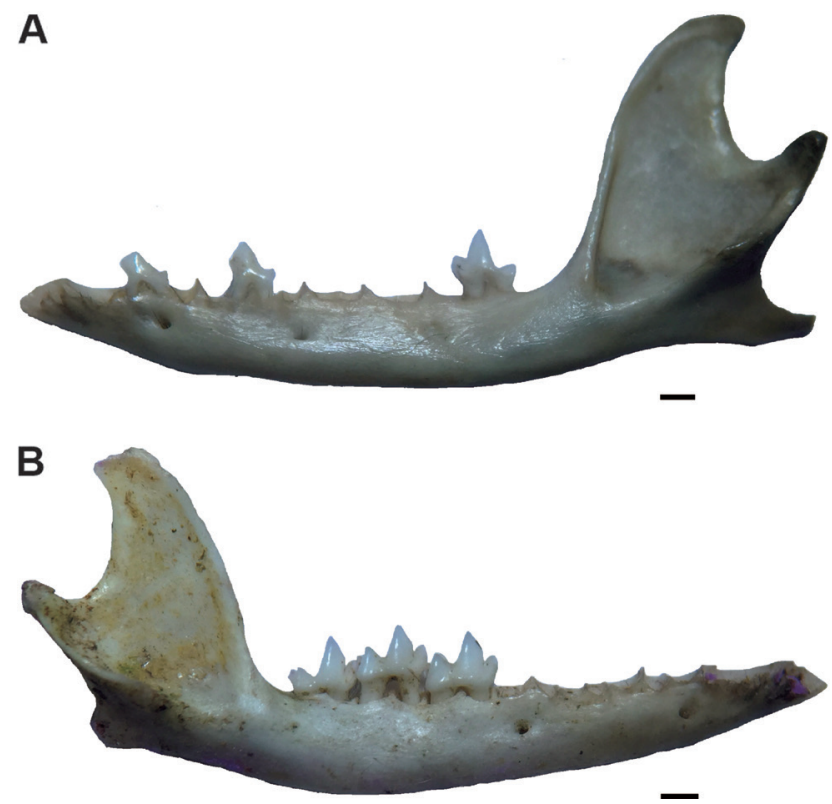

Figure 2. Didelphimorphia specimens from the Tyto furcata pellets from the Municipality of São Lourenço do Sul, State of Rio Grande do Sul, Brazil. (A) = labial view of the left dentary of Cryptonanus guahybae, UFSC-CF 32-2-1. (B) = labial view of the right dentary of Gracilinanus microtarsus, UFSC-CF 42-10-1. Scale bars: $1 \mathrm{~mm}$.
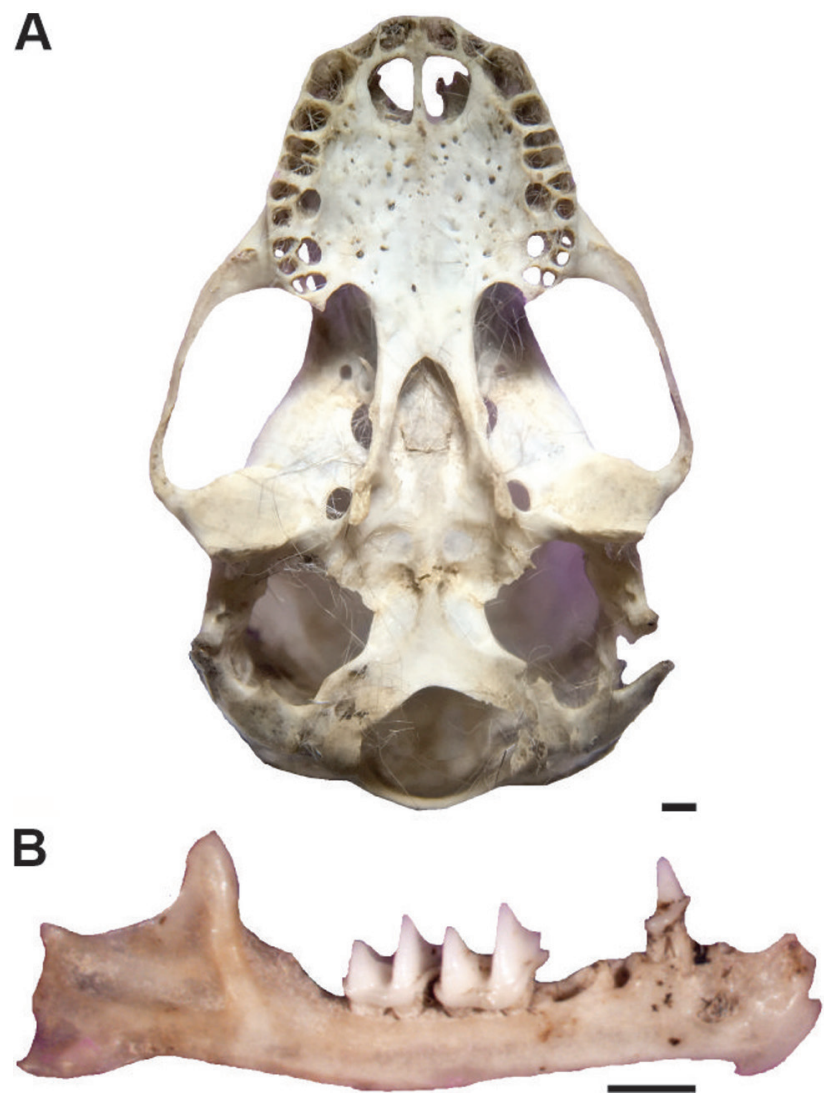

Figure 3. Chiroptera specimens from the Tyto furcata pellets from the Municipality of São Lourenço do Sul, State of Rio Grande do Sul, Brazil. (A) = ventral view of the skull of Sturnira lilium, UFSC-CF 40-5-1. (B) = labial view of the right dentary of Tadarida brasiliensis, UFSC-CF 42-11-1. Scale bars: $1 \mathrm{~mm}$. 
rodents were dominant in the samples $(78.95 \%$ of the taxa and $99.46 \%$ of the individuals) and, among them, the cricetids prevailed $(63.16 \%$ and $71.23 \%$, respectively). Marsupials and chiropterans were represented by two taxa each, composing $0.42 \%$ and $0.12 \%$ of the total individuals, respectively. The greatest number of taxa was registered at site Picada Feliz I (16 taxa), followed by Evaristo II (11 taxa), Boqueirão (9 taxa), and Quevedos II (8 taxa) (Table 2).

Mus musculus, an exotic invasive murine, was registered in all of the sites. Moreover, Akodon spp., Calomys sp., and Oligoryzomys sp. were registered in 11
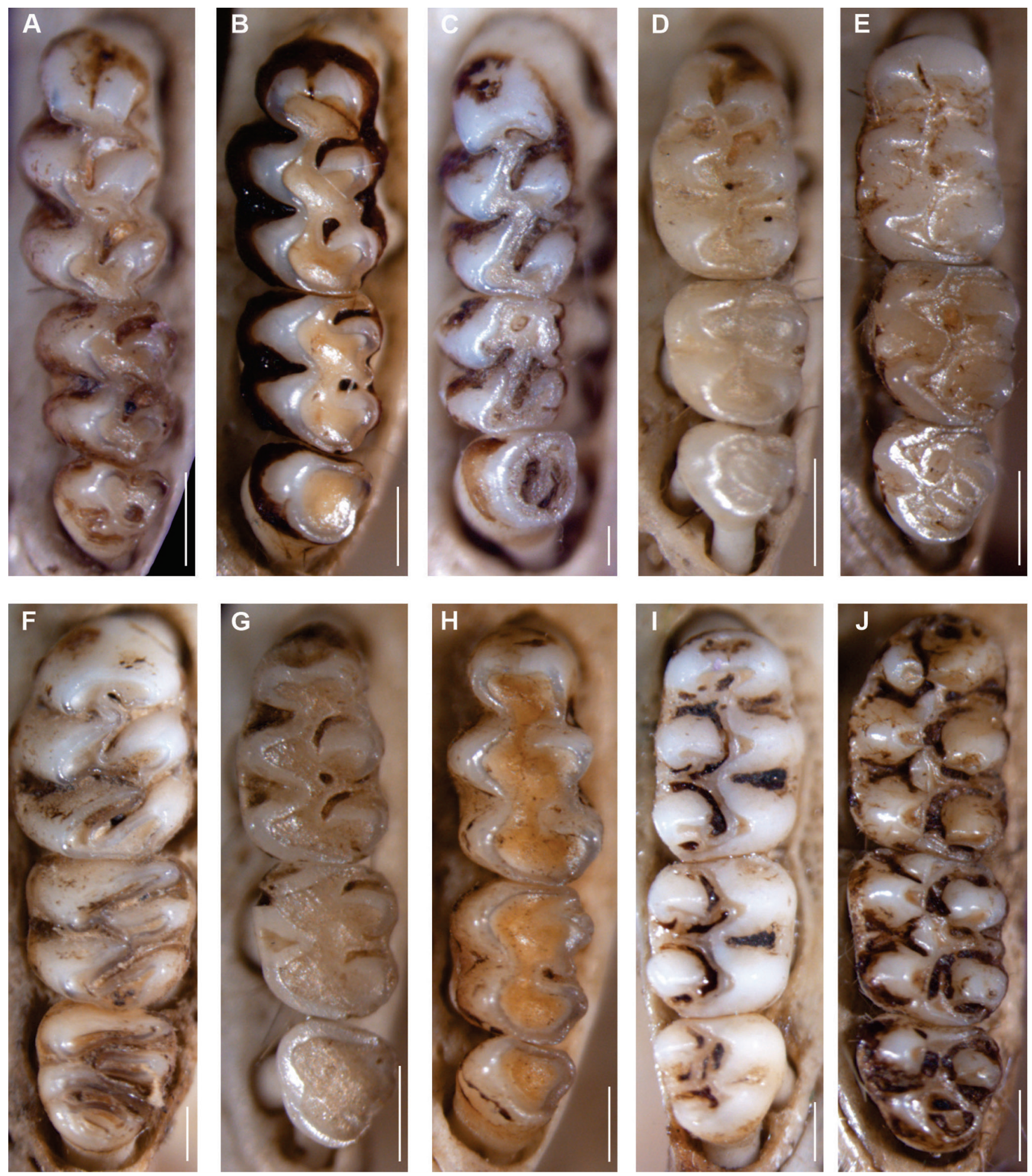

Figure 4. Occlusal view of the upper molars of the Sigmodontine rodents from the Tyto furcata pellets from the Municipality of São Lourenço do Sul, State of Rio Grande do Sul, Brazil. (A) = Akodon azarae, UFSC-CF 43-2-1, left M1-M3. (B) = Akodon sp., UFSC-CF 32-4-1, left M1-M3. (C) = Bibimys sp., UFSC-CF 32-5-1, left M1-M3. (D) = Calomys sp., UFSC-CF 32-6-1, left M1-M3. (E) = Juliomys sp., UFSC-CF 32-7-1, left M1-M3. (F) = Holochilus sp., UFSC-CF 43-4-1, left M1-M3. (G) = Oligoryzomys sp., UFSC-CF 32-11-1, left M1-M3. (H) = Oxymycterus sp., UFSC-CF 32-12-1, left M1-M3. (I) = Sooretamys angouya, UFSC-CF 32-13-1, right M1-M3. $(\mathrm{J})=$ Wilfredomys oenax, UFSC-CF 32-14-1, left M1-M3. Scale bars: $\mathrm{C}=200 \mu \mathrm{m} ; \mathrm{A}, \mathrm{B}, \mathrm{D}, \mathrm{E}, \mathrm{F}, \mathrm{G}, \mathrm{H}, \mathrm{I}, \mathrm{J}=500 \mu \mathrm{m}$. 
sites, being absent only in the smaller sample (Reserva). Five taxa (Tadarida brasiliensis, Sturnira lilium, Akodon azarae, Juliomys sp., and Lundomys molitor) occurred only in one site. Oligoryzomys sp. represented $52.5 \%$ of the recorded individuals, being the most frequent taxon in ten of the 12 studied sites, followed by M. musculus (28.28\%; most frequent in Picada das Antas), Calomys sp. (7.64\%), and Akodon spp. (6.07\%). The other 12 taxa together represented $5.46 \%$ of the individuals. Wilfredomys oenax, a threatened species ("endangered" at the global level and "critically endangered" at the national and state levels), was reported for three sites (Evaristo II, Picada Feliz I, and Quevedos I).
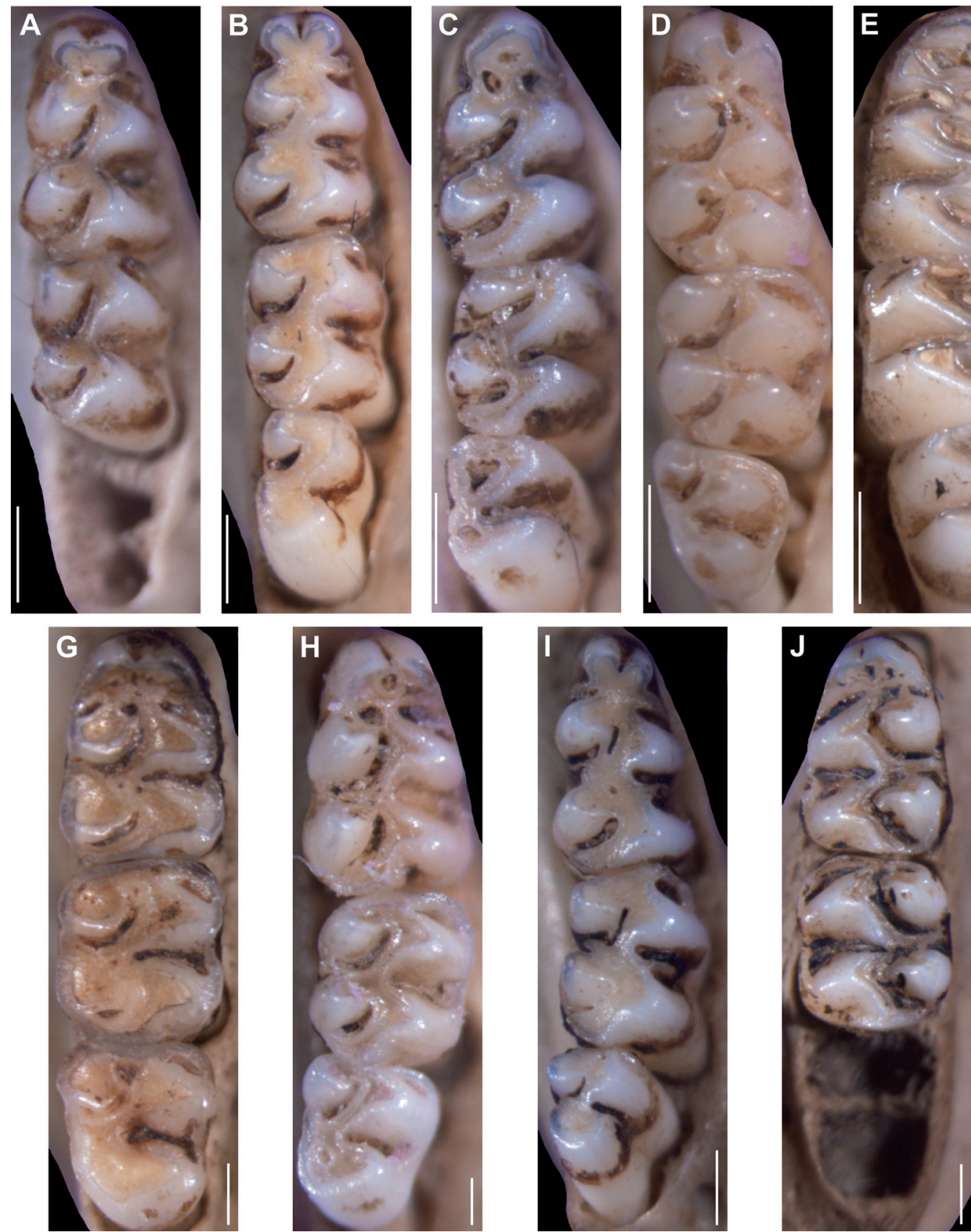

Akodon azarae, one of the smallest Brazilian species of Akodon, was present in the SLS pellets, represented by a skull, one isolated maxillary, and six dentaries from the site Quevedos II. The skull possesses complete upper molar rows, measuring LM1-M3 = $3.98 \mathrm{~mm}$. In addition, the specimens present an alveolar LM1-M3 $=4.04$ to $4.1 \mathrm{~mm}$ $(\mathrm{n}=2)$ and very deep anteromedian flexi/flexids, allowing their attribution to A. azarae following Hershkovitz (1990). The other specimens were treated as Akodon spp. They included maxillae with longer molar series $(n=53$, LM1-M3 = 4.2 to $4.82 \mathrm{~mm}$ ), which could be referred to A. montensis Thomas, 1913 (relatively shorter molar series) or A. paranaensis Christoff et al., 2000 or A. reigi

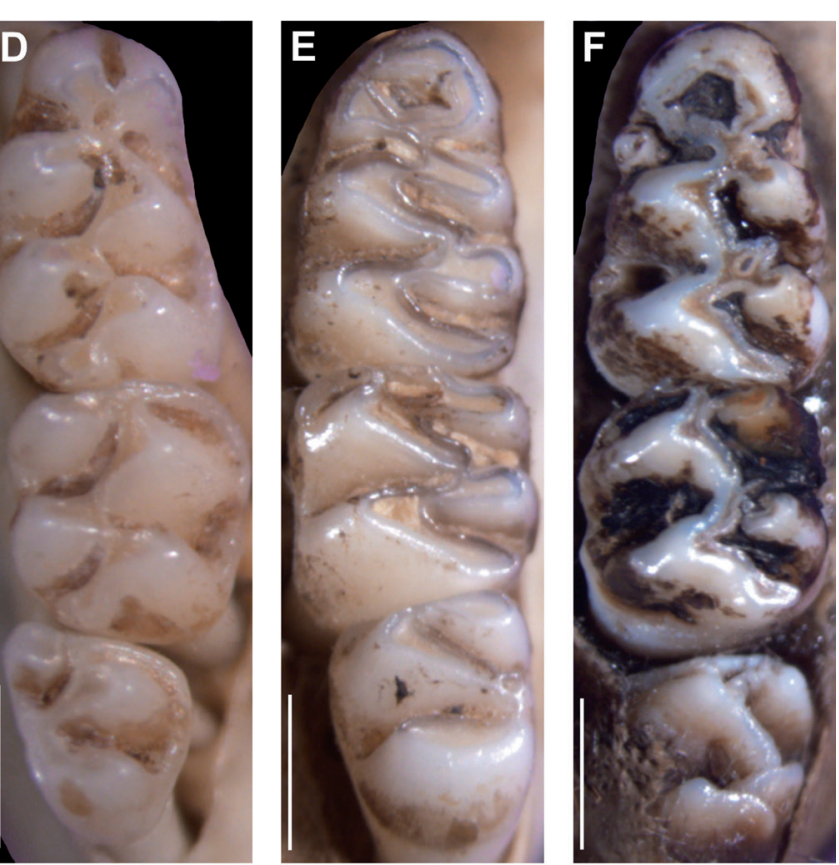

Figure 5. Occlusal view of the lower molars of the Sigmodontine rodents from Tyto furcata pellets from the Municipality of São Lourenço do Sul, State of Rio Grande do Sul, Brazil. (A) = Akodon azarae, UFSC-CF 43-2-2, right m1-m2. (B) = Akodon sp., UFSC-CF 32-4-2, right m1-m3; (C) = Bibimys sp., UFSC-CF 32-5-2, right m1-m3. (D) = Calomys sp., UFSC-CF 32-6-2, right m1-m3. (E) = Holochilus sp., UFSC-CF 43-4-2, left m1-m3. (F) = Lundomys molitor, UFSC-CF 32-9-1, left m1-m3. (G) = Nectomys squamipes, UFSC-CF 32-10-1, right m1-m3. (H) = Oligoryzomys sp., UFSC-CF 32-11-2, right m1-m3. (I) = Oxymycterus sp., UFSC-CF 32-12-2, right m1-m3. (J)= Sooretamys angouya, UFSC-CF 32-13-2, left m1-m2. (K) = Wilfredomys oenax, UFSC-CF 32-14-2, left m1-m3. Scale bars: $H=200 \mu m ; A, B, C, D, G, I, J, K=500 \mu m ; E, F=1$ mm. 
Table 2. Minimum number of individuals per taxon of small mammals registered in Tyto furcata pellets from the municipality of São Lourenço do Sul, State of Rio Grande do Sul, Brazil. The sites abbreviations follow Table 1.

\begin{tabular}{|c|c|c|c|c|c|c|c|c|c|c|c|c|c|c|}
\hline Taxon & BV1 & BV2 & BOQ & CGA & EV1 & EV2 & ANT & PF1 & PF2 & QV1 & QV2 & RES & Total & $\%$ \\
\hline \multicolumn{15}{|l|}{ Didelphimorphia } \\
\hline \multicolumn{15}{|l|}{ Didelphidae } \\
\hline Cryptonanus guahybae (Tate, 1931) & & & 1 & & & 1 & & 7 & & & & & 9 & 0,34 \\
\hline Gracilinanus microtarsus (Wagner, 1842) & & & & & & 1 & & 1 & & & & & 2 & 0,08 \\
\hline \multicolumn{15}{|l|}{ Chiroptera } \\
\hline \multicolumn{15}{|l|}{ Molossidae } \\
\hline Tadarida brasiliensis (I. Geoffroy, 1824) & & & & & & 1 & & & & & & & 1 & 0,04 \\
\hline \multicolumn{15}{|l|}{ Phyllostomidae } \\
\hline Sturnira lilium (E. Geoffroy, 1810) & & & & & 2 & & & & & & & & 2 & 0,08 \\
\hline \multicolumn{15}{|l|}{ Rodentia } \\
\hline \multicolumn{15}{|l|}{ Cricetidae } \\
\hline Akodon azarae (J. Fischer, 1829) & & & & & & & & & & & 3 & & 3 & 0,11 \\
\hline Akodon spp. & 9 & 4 & 9 & 2 & 4 & 15 & 2 & 104 & 4 & 3 & 3 & & 159 & 6,08 \\
\hline Bibimys sp. & & & & & & 2 & & 10 & 1 & & & & 13 & 0,50 \\
\hline Calomys sp. & 5 & 5 & 3 & 5 & 13 & 21 & 10 & 122 & 3 & 3 & 10 & & 200 & 7,64 \\
\hline Juliomys sp. & & & & & & & & 1 & & & & & 1 & 0,04 \\
\hline Holochilus sp. & & & 1 & & & & & 3 & & & 3 & & 7 & 0,27 \\
\hline Lundomys molitor (Winge, 1887) & & & & & & & & 1 & & & & & 1 & 0,04 \\
\hline Nectomys squamipes (Brants, 1827) & & & & & & 1 & & 1 & & & & & 2 & 0,08 \\
\hline Oligoryzomys sp. & 41 & 21 & 42 & 26 & 26 & 145 & 23 & 949 & 38 & 13 & 50 & & 1374 & 52,5 \\
\hline Oxymycterus nasutus (Waterhouse, 1837) & 1 & 1 & 4 & 1 & & 4 & 3 & 51 & & & 8 & 1 & 74 & 2,83 \\
\hline Sooretamys angouya (G. Fischer, 1814) & & 1 & 1 & 1 & & & 1 & 3 & & & & 2 & 9 & 0,34 \\
\hline Wilfredomys oenax (Thomas, 1928) & & & & & & 3 & & 7 & & 1 & & & 11 & 0,42 \\
\hline \multicolumn{15}{|l|}{ Muridae } \\
\hline Mus musculus Linnaeus, 1758 & 15 & 20 & 32 & 4 & 9 & 22 & 33 & 564 & 12 & 2 & 26 & 1 & 740 & 28,28 \\
\hline Rattus rattus (Linnaeus, 1758) & & & 2 & & & & & 5 & & & & & 7 & 0,27 \\
\hline \multicolumn{15}{|l|}{ Caviidae } \\
\hline Cavia aperea Erxleben, 1777 & & & & & & & & 1 & & & 1 & & 2 & 0,08 \\
\hline MNI & 71 & 52 & 95 & 39 & 54 & 216 & 72 & 1830 & 58 & 22 & 104 & 4 & 2617 & 100,00 \\
\hline Richness (small mammals total) & 5 & 6 & 9 & 6 & 5 & 11 & 6 & 16 & 5 & 5 & 8 & 3 & 19 & \\
\hline
\end{tabular}

González et al., 1998 (relatively longer molar series), following Gonçalves et al. (2007). However, the absence of clear diagnostic characters and the fragmentary nature of the studied specimens prevent species determination.

The genus Bibimys was represented by a $\mathrm{MNI}=13$ in three SLS samples (Evaristo II, Picada Feliz I and II). The uncertain taxonomic status and subtle cranial traits of the three species recognized for this genus preclude reliably assigning these specimens to one particular species (Pardiñas et al., 2015a, 2017a). Populations recorded in $\mathrm{RS}$ are referred to $B$. labiosus (Winge, 1887) (e.g., Pardiñas et al., 2015a; Machado et al., 2016), which is a plausible hypothesis for the SLS specimens pending a revision of a more extensive set of traits (e.g., molecular data).

Two species of Calomys are mentioned for RS: C. tener (Winge, 1887) and C. laucha (G. Fischer, 1814) (Haag et al., 2007; Quintela et al., 2014; González-Ittig et al., 2019). The SLS specimens belonging to this genus possess a distinctively prominent supraorbital margin, large sphenopalatine vacuities, and a generally conspicuous capsular projection. These features are commonly attributed to $C$. tener. Nevertheless, the studied material also presents an M3 with a shallow hypoflexus and a "W-shaped" $\mathrm{m3}$, which are reported as characteristics of C. laucha (Salazar-Bravo, 2015). Thus, the specific assignment of the studied material was not possible.
One specimen of the arboreal mouse Juliomys was registered in the Picada Feliz I sample. The generic attribution is supported by its short and broad palate and the complex morphology of the brachydont molars, which possess a broad procingulum, well-developed anteromedian flexus, mesoloph, and developed enteroloph in $\mathrm{M} 1$; and an anterostyle in M2. The features preserved in this specimen do not allow its assignment to one of the three species recorded in RS, J. ossitenuis Costa et al., 2007, J. pictipes (Osgood, 1933), and J. ximenezi Christoff et al., 2016.

Holochilus and Lundomys are semiaquatic rats, and are also present in the SLS pellets, the former registering in three sites (Boqueirão, Picada Feliz I, and Quevedos II) and the latter in only one site (Picada Feliz I). Two species of Holochilus occur currently in RS, $H$. brasiliensis (Desmarest, 1819) and H. vulpinus (Brants, 1827), both belonging to the $H$. brasiliensis group (Pardiñas et al., 2013; D'Elía et al., 2015). Dental differences between these species are poorly addressed, precluding the specific assignment of the fragmentary material. The identification of Lundomys was based on the following features: a low coronoid process; poorly developed capsular projection (compared to Holochilus); masseteric crests which do not join together and which extend farther from the mentonian process than in Holochilus; flexi and flexids shallow- 
er than in Holochilus and non-interpenetrating; an M1/ $\mathrm{m} 1$ and $\mathrm{M} 2 / \mathrm{m} 2$ with a small and distinct mesoloph/mesolophid; a procingulum divided by a small anteromedian flexus, which is absent in Holochilus; and an M2 with a protoflexus (Voss \& Carleton, 1993).

The genus Oligoryzomys comprises two species in Southern Brazil, O. flavescens (Waterhouse, 1837) and O. nigripes (Olfers, 1818), which are reported as being very similar in metrics and cranial morphology (Pardiñas et al., 2017b). Some characters, such as the length of the upper molar series, the length of the incisive foramen, the position of the frontal (or suprafrontal) foramen, and the development of the capsular projection on the dentary, have already been considered diagnostic for these two species (Langguth, 1963; Machado et al., 2011;
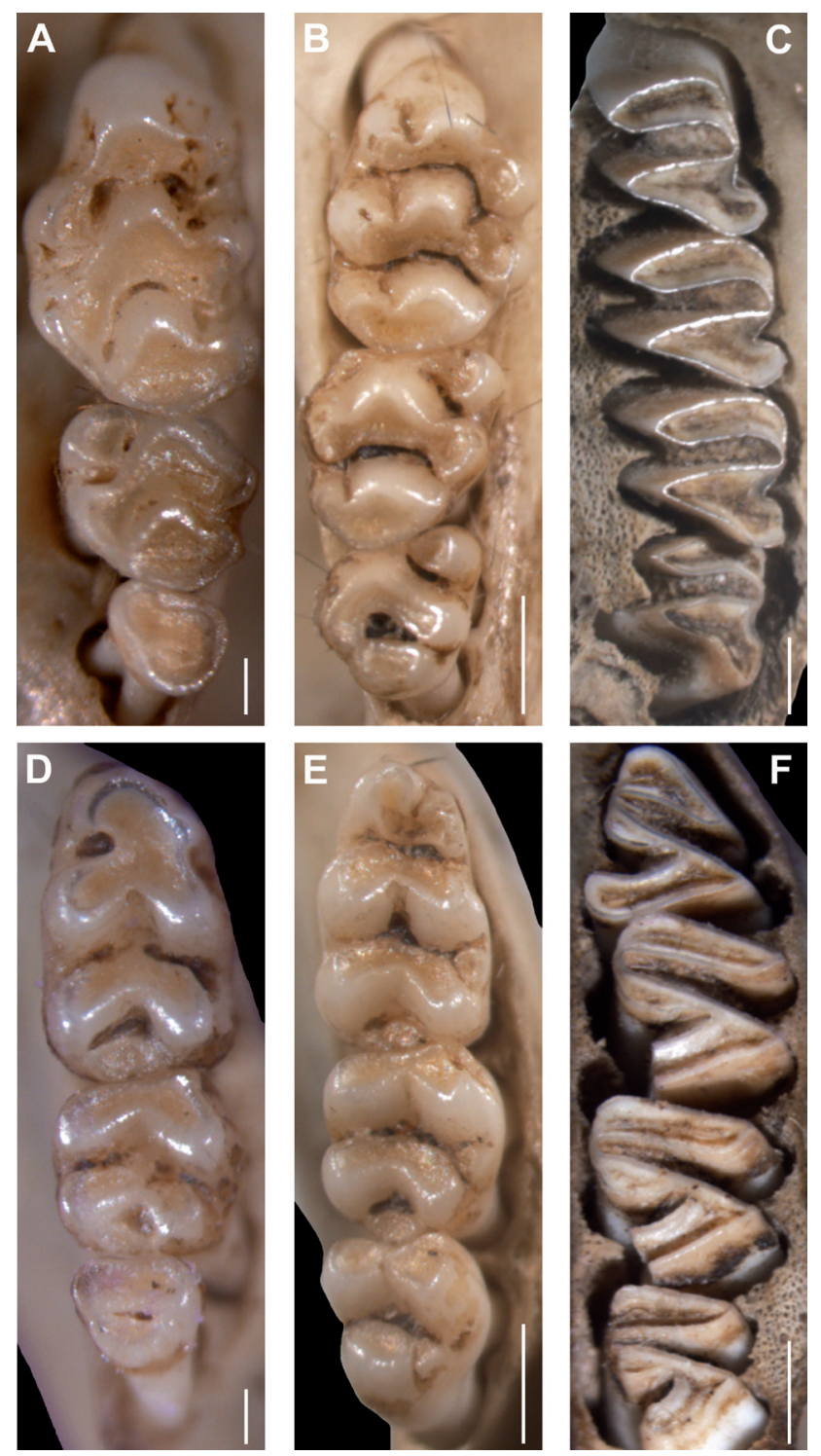

Figure 6. Occlusal view of the upper and lower molars of the Muridae and Caviidae rodents from Tyto furcata pellets from the Municipality of São Lourenço do Sul, State of Rio Grande do Sul, Brazil. (A) = Mus musculus, UFSC-CF 32-15-1, left M1-M3. (B) = Rattus rattus, UFSC-CF 35-9-1, right M1-M3. (C) = Cavia aperea, UFSC-CF 43-8-1, left P4-M3. (D) = M. musculus, UFSC-CF 32-15-2, right m1-m3. $(\mathrm{E})=$ R. rattus, UFSC-CF 35-9-2, right m1-m3. $(\mathrm{F})=$ C. aperea, UFSC-CF 43-8-2, right p4-m3. Scale bars $A, D=200 \mu m ; B, C, E, F=1 \mathrm{~mm}$.
Boroni et al., 2015). Nevertheless, these features showed some variation in the material used for comparison (see the discussion in Cherem et al., 2018). Thus, the SLS specimens were identified only as Oligoryzomys sp.

\section{DISCUSSION}

\section{Semi-deciduous Seasonal Forests in the Brazilian Pampa: small mammal taxonomy}

Although we uncritically referred the studied Lundomys material to the single species today recognized for the genus, L. molitor (Winge, 1887), it is important to note that the species has its type locality in Lagoa Santa, Minas Gerais, about 1,500 km northeast of SLS, where it became extinct (Voss \& Carleton, 1993; Pardiñas \& Teta, 2013). Today, L. molitor is mostly known from populations in the Uruguayan territory and three adjacent Brazilian localities (Silveira et al., 2011; Voss, 2015; Brandão \& Fegies, 2017). In addition, differences in molar morphology have been highlighted between the Lagoa Santa material and living samples (Pardiñas \& Teta, 2011). More important to the focus of the present study, Brandão \& Fegies (2017) reported subtle differential traits between individuals from SLS and Uruguay. In this context, the nominal form Holochilus magnus, erected by Hershkovitz (1955) with a type locality in eastern Uruguay, deserves attention for its potential value in a much needed revision of Lundomys.

The case of the arboreal cricetid Wilfredomys seems to have some parallelism with that described above for Lundomys. Wilfredomys oenax, the type and single species recognized for the genus, was described based on material collected in SLS (Thomas, 1928). This rat has a large geographic range, including most of the Uruguayan territory and also isolated enclaves in the Brazilian states of Paraná and São Paulo (González et al., 2015). Vaz Ferreira (1960) highlighted differences between the type material and one specimen from Uruguay, and Pine (1980: 198) expanded these comparisons and concluded "further study may show that the Brazilian and Uruguayan populations are worthy of subspecific designation." Our knowledge about the alpha taxonomy of Wilfredomys is poor (Machado et al., 2015), and specimens available for study are so scarce and fragmentary (Brandão, 2015) that non-geographic variation is difficult to assess (González et al., 2015: 106). However, taking into account that $W$. oenax comes from the hilly surroundings of SLS, despite its geographic proximity to Uruguayan localities, environmental differences could be associated with the reported variability.

The alpha taxonomy of Juliomys, a small forest dweller, deserves attention, especially regarding its southernmost expressions. With the recent description of $J$. ximenezi, a new species was added to the pool of Juliomys species reported for the southern portion of the Atlantic Forest, totaling three forms including J. pictipes and J. ossitenuis (Christoff et al., 2016). This is a striking case of sympatry because they are phenotypically very 
similar (Pavan \& Leite, 2011), suggesting no major niche differences among them. If the diversity of the assemblage is not artifactual (i.e., misidentifications), clearly a working hypothesis is needed to explain the recorded sympatry. In sharp contrast, populations of Juliomys in Misiones Province, Argentina, are exclusively attributed to a single species, J. pictipes (Pardiñas et al., 2008). The material recovered in SLS, extending the southern limit of the distribution of this genus by around $250 \mathrm{~km}$, could represent an important piece of information to clarify the taxonomy of Juliomys in its southern range. Since most of the current understanding of the alpha taxonomy of Juliomys is based on genetic data, the growing possibility of extracting DNA from remains retrieved from owl pellets is exciting.

The current alpha taxonomy of the rare akodontine Bibimys, which includes three species, is mostly based on subtle cranial and genetic differences (D'Elía et al., 2005; Gonçalves et al., 2005; Pardiñas et al., 2015a). The Brazilian samples are traditionally referred to $B$. I $a$ biosus (see Grazzini et al., 2015; Pardiñas et al., 2015a), but the populations from the grasslands of southern Misiones Province (Argentina), not far from SLS, are referred to B. chacoensis (Pardiñas et al., 2017a). The SLS record enlarges the known distribution of this genus by about $450 \mathrm{~km}$ to the south in Brazil, but its specific assignment needs to be strengthened; again, the possibility to extract DNA from owl pellet material seems a plausible way to do that. In addition, since SLS is about $200 \mathrm{~km}$ from the Uruguayan border, a future record of Bibimys in that country is not unlikely, taking into account the environmental continuity between southernmost RS and the Cerro Largo department (Brazeiro et al., 2008).

\section{Semi-deciduous Seasonal Forests in the Brazilian Pampa: small mammal biogeography}

The SLS small mammal assemblage as revealed by the owl pellet samples studied here is composed of a mixture of species with different ecological affinities. The perceptible dominance of Oligoryzomys (possibly including $O$. flavescens and $O$. nigripes) reflects disturbed environments, since this genus includes opportunistic invasive species in cleared areas of the Atlantic Forest (Fonseca \& Kierluff, 1989; Pardini \& Umetsu, 2006; Melo et al., 2011). The moderate abundance of Calomys (possibly including C. laucha and C. tener), typically a grassland phyllotine, seems in line with the extensive implementation of agroecosystems (Bilenca et al., 1992; Courtalon et al., 2003; Castellarini et al., 2011). The occurrence of Pampean and high-elevation grassland elements, such as Akodon azarae and Oxymycterus nasutus (Bilenca et al., 1992; Paise \& Vieira, 2006; Sponchiado et al., 2012; Oliveira \& Gonçalves, 2015), reinforces the notion that these species are intruders favored by forest clearance. However, a small group of primarily sylvan (e.g., Gracilinanus microtarsus, Juliomys sp., Sooretamys angouya) or scrub and perisylvan grass-associated (e.g., Bibimys sp., Wilfredomys oenax) species (Pardini \& Umetsu, 2006; González et al., 2015) probably represent the original core of the SLS assemblage. Fragmented populations of these mammals surely survive favored by gallery forests which normally bordered watercourses coupled with occasional patches of forest and scattered trees that covered the top of the hills. Clearly, these marsupials and rodents are penetrating into the area from more densely forested areas in the northeastern part of RS, and some of them reach their southernmost occurrences in or close to SLS (Juliomys, Nectomys, Sooretamys).

The SLS small mammal assemblage reflects a biogeographical mixture. Hershkovitz (1958), in his seminal contribution exploring mammal units within the Neotropics, crossed southernmost RS with the limit between Brazilian (to the east) and Patagonian (to the west) subregions. In a more focused geographical approach, González (2000) argued for the displacement of this boundary to the south, dissecting Uruguay centrally. The latter author also recognized an assemblage of Platan mammals (alluding to the Río de la Plata fluvial system), in which he included several of the rodents recorded in SLS, such as A. azarae, Lundomys, and Wilfredomys (González, 2000: fig. 1). In this context, the SLS assemblage could be interpreted as a mixed fauna composed of Pampean and Platan elements interpenetrated by Atlantic Forest invasive species. One of the most comprehensives studies to explore the biogeography of the Atlantic Forest was conducted by Pires et al. (2000) based on a cladistic analysis of the distribution of marsupials, rodents, and primates. According to their results, the southern portion of this biome is retrieved in a polytomy, revealing a poor community structure in sharp contrast to the central and northern portions. These findings suggest that these regions, where SLS and the Semi-deciduous Seasonal Forest of southwestern RS are included, support mixed ecotonal micromammal assemblages mostly infiltrated by those Atlantic Forest elements with greater ecological lability. Corroborating this, Juliomys sp., Nectomys squamipes, and Sooretamys angouya, and perhaps Akodon montensis, were recorded in SLS. Juliomys and Sooretamys were genera hitherto considered endemic to the Atlantic Forest Biome (Paglia et al., 2012), while N. squamipes, a semiaquatic rodent, is strongly associated with this biome and the adjacent Cerrado gallery forests (Bonvicino \& Weksler, 2015). Akodon montensis has a wider distribution, from eastern Paraguay and northeastern Argentina to the coast of Brazil (Pardiñas et al., 2015b), but has been associated with a closed and dense microhabitat (e.g., a higher percentage of canopy cover or abundance of bamboo) in the Brazilian Atlantic Forest Biome (Geise et al., 2004; Dalmagro \& Vieira, 2005; Lima et al., 2010). Thus, the southeastern extension of the range of these species, penetrating into the Pampa Biome, is due to presence of the Semi-deciduous Seasonal Forest at high latitudes. A similar pattern was reported by Lima et al. (2010), who recorded $A$. montensis, Juliomys sp., and $S$. angouya in a deciduous forest area on the austral boundary of the Atlantic Forest in central RS. 


\section{Rapid inventories in human-changing ecosystems: owl pellet value}

Several studies have stressed the importance of owl pellet analysis in small mammal surveys (e.g., Bonvicino \& Bezerra, 2003; Formoso et al., 2016; Mancini et al., 2018), and this was also corroborated by the present work. The data obtained in SLS reveal a rich small mammal community occurring in a forested portion of the Pampa Biome in Southern Brazil, including at least 17 taxa of non-volant small mammals and two chiropterans. This is the richest owl pellet sample studied in RS to date (Cherem et al., 2018, 10 taxa; González et al., 1999, 11 taxa; Peters et al., 2010, 13 taxa; Scheibler \& Christoff, 2007, 16 taxa), and one of the richest reported in South America (e.g., Baglan \& Catzeflis, 2016, 12 species in coastal savannas in French Guiana; Fernández et al., 2012, 13 species in Quiñihual, Argentinean Pampa; Massoia et al., 1990, 14 species in Desaguadero, Argentinean wetlands; Brito et al., 2015, 14 species in Los Santiagos, Ecuador; Bonvicino \& Bezerra, 2003, 16 species in Brazilian Cerrado; Lemos et al., 2015, 17 species in coastal Rio de Janeiro, Brazil; Mancini et al., 2018, 26 species in caves of the Caatinga, Northeastern Brazil).

Therefore, we highly recommend the analysis of owl pellet samples as an efficient, non-invasive and low-cost method to record small mammals in vast and poorly known Neotropical territories. Despite the material being fragmentary, it is possible to achieve great taxonomic resolution through comparison with specimens housed in scientific collections and the literature. Furthermore, molecular analysis could also be used to elucidate the taxonomic identity of several taxa with poorly resolved taxonomies (Buś et al., 2014; Rocha et al., 2015). An increase in morphological studies is desirable to help in the identification of the material retrieved from owl pellets.

\section{ACKNOWLEDGEMENTS}

We would like to thank João Pedro Hammes, José Carlos Dilli, Edla da Silva, Gilberto Griep, Renato Schmafiss, Daniele Radtke, Laercio Timm, and Guilherme Renato Schinid for the access to the sampling sites, and, particularly, Carmem Milbrath, for all the support during the fieldwork. We also thank Vitor Zimmermann for the map elaboration; the Laboratório Multiusuário de Estudos em Biologia (LAMEB-UFSC) for the photos; Katarzyna Piper for the English review; and the two anonymous reviewers for their valuable suggestions.

\section{FUNDING}

Financial support for this study was given by the Conselho Nacional de Desenvolvimento Científico e Tecnológico, Brazil (CNPq 444508/2014-7) (PH), and the Agencia Nacional de Promoción Científica y Tecnológica, Argentina (PICT 2014, \#1039) (UFJP).

\section{REFERENCES}

Avila-Pires, F.D. 1994. Mamíferos descritos do Estado do Rio Grande do Sul, Brasil. Revista Brasileira de Zoologia, 54(3): 367-384.

Baglan, A. \& Catzeflis, F. 2016. Barn owl pellets collected in coastal savannas yield two additional species of small mammals for French Guiana. Mammalia, 80(1): 91-95.

Barquez, R.M.; Mares, M.A. \& Braun, J.K. 1999. The bats of Argentina. Special Publications, Museum of Texas Tech University, 42: 1-275.

Beisaw, A.M. 2013. Identifying and interpreting animal bones: a manual. Texas, Texas A\&M University Press. 192p.

Belton, W. 1984. Birds of Rio Grande do Sul, Brazil. Part 1. Rheidae through Furnariidae. Bulletin of the American Museum of Natural History, 178: 369-636.

Bilenca, D.N.; Kravetz, F.0. \& Zuleta, G.A. 1992. Food habits of Akodon azarae and Calomys laucha (Cricetidae, Rodentia) in agroecosystems of central Argentina. Mammalia, 56(3): 371-383.

Bonvicino, C.R. \& Bezerra, A.M.R. 2003. Use of regurgitated pellets of barn owl (Tyto alba) for inventorying small mammals in the Cerrado of Central Brazil. Studies on Neotropical Fauna and Environment, 38(1): 1-5.

Bonvicino, C.R. \& Weksler, M. 2015. Genus Nectomys Peters, 1861. In: Patton, J.L.; Pardiñas, U.F.J. \& D'Elía, G. (Eds.). Mammals of South America. Vol. 2. Chicago, The University of Chicago Press. p. 369-377.

Boroni, N.L.; Pardiñas, U.F.J. \& Lessa G. 2015. Oligoryzomys fornesi (Massoia, 1973), Mammalia, Rodentia, Sigmodontinae: distribution extension. Boletim do Museu de Biologia Mello Leitão, 37(3): 301-311.

Brandão, M.V. 2015. The occurrence of Wilfredomys oenax (Rodentia: (ricetidae: Sigmodontinae) in São Paulo State, southeastern Brazil: a locally extinct species? Papeis Avulsos de Zoologia, 55(4): 69-80.

Brandão, M.V. \& Fegies, A.C. 2017. Range extension of Lundomys molitor (Winge, 1887) (Mammalia: Rodentia: Cricetidae) to eastern Rio Grande do Sul state, Brazil. Check List, 13(2): 2101.

Brazeiro, A.; Achkar, M.; Canavero, A.; Fagúndez, C.; González, E.; Grela, I.; Lezama, F.; Maneyro, R.; Barthesagy, L.; Camargo, A.; Carreira, S.; Costa, B.; Núñez, D.; da Rosa, I. \& Toranza, C. 2008. Prioridades geográficas para la conservación de la biodiversidad terrestre de Uruguay. Resumen Ejecutivo. Proyecto PDT 32-26. 51p.

Brito, J.M.; Orellana-Vásquez, H.; Cadena-Ortiz, H.; Vargas, R.; Pozo-Zamora, G.M. \& Curay, J. 2015. Mamíferos pequeños en la dieta de la lechuza Tyto alba (Strigiformes: Tytonidae) en dos localidades del occidente de Ecuador, con ampliación distribucional de Ichthyomys hydrobates (Rodentia: Cricetidae). Papeis Avulsos de Zoologia, 55(19): 261-268.

Buś, M.M.; Żmihorski, M.; Romanowski, J.; Balčiauskienė, L.; Cichocki, J. \& Balčiauskas, L. 2014. High efficiency protocol of DNA extraction from Micromys minutus mandibles from owl pellets: a tool for molecular research of cryptic mammal species. Acta Theriologica, 59(1): 99-109.

Castellarini, F.; Dellafiore, C. \& Polop, J. 2011. Feeding habits of small mammals in agroecosystems of central Argentina. Mammalian biology, 68(2): 91-101.

Cherem, J.J.; Hadler, P.; Stutz, N.S. \& Pardiñas, U.F.J. 2018. Pequenos mamíferos (Didelphimorphia, Chiroptera e Rodentia) em egagropilos de Tyto furcata (coruja-das-igrejas) (Aves, Tytonidae) do sul do Brasil. Biotemas, 31(3): 43-58.

Christoff, A.U.; Vieira, E.M.; Oliveira, L.R.; Gonçalves, J.W.; Valiati, V.H. \& Tomasi, P.S. 2016. A new species of Juliomys (Rodentia, Cricetidae, Sigmodontinae) from the Atlantic Forest of Southern Brazil. Journal of Mammalogy, 97(5): 1469-1482.

Cordeiro, J.L.P. \& Hasenack, H. 2009. Cobertura vegetal atual do Rio Grande do Sul. In: Pillar, V.D.; Müller, S.C.; Castilhos, Z.M.S. \& Jacques, A.V.A. (Eds.). Campos Sulinos - conservação e uso sustentável da biodiversidade. Brasília, Ministério do Meio Ambiente. p. 285-299. 
Courtalon, P.; Dolcemascolo, A.; Troiano, V.; Álvarez, M.R. \& Busch, M. 2003. Inter and intraspecific relationships in Akodon azarae and Calomys laucha (Rodentia, Sigmodontinae) in pampean agroecosystems. Mastozoología Neotropical, 10(1): 27-39.

D'Elía, G.; Pardiñas, U.F.J.; Myers, P. 2005. An Introduction to the Genus Bibimys (Rodentia: Sigmodontinae): Phylogenetic Position and Alpha Taxonomy. In: Lacey, E.A. \& Myers, P. (Eds.). Mammalian diversification: from chromosomes to phylogeography. Berkeley, University of California Press. p. 147-182.

D'Elía, G.; Hanson, D.; Mauldin, M.; Teta, P. \& Pardiñas, U.F.J. 2015. Molecular systematics of the South American marsh rats of the genus Holochilus (Muroidea, Cricetidae, Sigmodontinae). Journal of Mammalogy, 96(5): 1081-1094.

Dalmagro, A.D. \& Vieira, E.M. 2005. Patterns of habitat utilization of small rodents in an area of Araucaria forest in Southern Brazil. Austral Ecology, 30(4): 353-362.

Fernández, F.J.; Idoeta, F.; Esponda, C.G.; Carrera, J.D.; Ballejo, F.; De Santis, L.J.M. \& Moreira, G.J. 2012. Small mammals (Didelphimorphia, Rodentia and (hiroptera) from pampean region, Argentina. Check List, 8(1): 130-134.

Fonseca, G.A.B. \& Kierulff, M.C.M. 1989. Biology and natural history of Brazilian Atlantic Forest small mammals. Bulletin of the Florida State Museum, Biological Sciences, 34(3): 99-152.

Formoso, A.; Teta, P.; Carbajo, A. \& Pardiñas, U.F.J. 2016. Unraveling the patterns of small mammal species richness in the southernmost aridlands of South America. Journal of Arid Environments, 134: 136-144.

Gardner, A.L. (Ed.). 2008. Mammals of South America. Vol. 1. Chicago, University of Chicago Press.

Geise, L.; Pereira, L.G.; Bossi, D.E.P. \& Bergallo, H.G. 2004. Pattern of elevational distribution and richness of nonvolant mammals in Itatiaia National Park and its surroundings, in southeastern Brazil. Brazilian Journal of Biology, 64(3B): 599-612.

Gonçalves, P.R.; Myers, P.; Vilela, J.F. \& Oliveira, J.A. 2007. Systematics of species of the genus Akodon (Rodentia: Sigmodontinae) in Southeastern Brazil and implications for the biogeography of the campos de altitude. Miscellaneous Publications, Museum of Zoology, University of Michigan, 197: 1-24.

Gonçalves, P.R.; Oliveira, J.A.; Corrêa, M.0. \& Pessôa, L.M. 2005. Morphological and cytogenetic analyses of Bibimys labiosus (Winge, 1887) (Rodentia, Sigmodontinae): implications for its affinities with the Scapteromyine group. In: Lacey, E.A. \& Myers, P. (Eds.). Mammalian diversifcation: from chromosomes to phylogeography to phylogeography. Berkeley, University of California Press. p. 175-210.

González, E.M. 2000. Lista sistemática, afinidades biogeográficas, hábitos y hábitats de los mamíferos terrestres autóctonos de Uruguay (Mammalia): una introducción. In: Jornadas sobre animales silvestres, desarollo sustentable y medio ambiente. Montevideo, Comisión Ambientalista, Facultad de Veterinaria. p. 58-73.

González, E.M.; Claramunt, S.J. \& Saralegui, A.M. 1999. Mamíferos hallados en egagrópilas de Tyto alba (Aves, Strigiformes, Tytonidae) en Bagé, Rio Grande do Sul, Brasil. Iheringia, Série Zoologia, 86: 117-120.

González, E.M.; Oliveira, J.A. \& Pardiñas U.F.J. 2015. Genus Wilfredomys AvilaPires, 1960. In: Patton, J.L.; Pardiñas, U.F.J. \& D'Elía, G. (Eds.). Mammals of South America. Vol. 2. Chicago, The University of Chicago Press. p. 105-107.

González-Ittig, R.E.; Narayan, P.K.; Bonvicino, C.R. \& Salazar-Bravo, J. 2019. Does the widely distributed rodent Calomys tener (Cricetidae: Sigmodontinae) constitute a single evolutionary unit? Zoologia, 36: e30354.

Grazzini, G.; Rezini, J.A.; Boraschi dos Santos, B.S.; Venâncio, F.J.; GattoAlmeida, F.; Sbalqueiro, I.J.; Hass, I. \& Tiepolo, L.M. 2015. Bibimys labiosus
Winge, 1887 (Mammalia: Rodentia: Sigmodontinae): new records in Paraná state, southern Brazil, and update of the known geographic distribution. Check List, 11(3): 1632.

Haag, T.; Muschner, V.C.; Freitas, L.B.; Oliveira, L.F.B.; Langguth, A.R. \& Mattevi, M.S. 2007. Phylogenetic relationships among species of the genus Calomys with emphasis on South American lowland taxa. Journal of Mammalogy, 88(3): 769-776.

Hadler, P.; Cherem, J.J.; Turbay, R.; Alberti, A. \& Pardiñas, U.F.J. 2016. Diversidade de pequenos mamíferos (Didelphimorphia e Rodentia) do Holoceno do nordeste do estado do Rio Grande do Sul, Brasil: implicações taxonômicas e paleoambientais. Revista Brasileira de Paleontologia, 19(1): 127-144.

Heisler, L.M.; Somers, C.M. \& Poulin, R.G. 2016. Owl pellets: a more effective alternative to conventional trapping for broad-scale studies of small mammal communities. Methods in Ecology and Evolution, 7(1): 96-103.

Hershkovitz, P. 1955. South American marsh rats, genus Holochilus, with a summary of sigmodont rodents. Fieldiana Zoology, 37(24): 639-673.

Hershkovitz, P. 1958. A geographic classification of neotropical mammals. Fieldiana Zoology, 36(6): 1-646.

Hershkovitz, P. 1990. Mice of the Akodon boliviensis size class (Sigmodontinae, (ricetidae), with the description of two new species from Brazil. Fieldiana Zoology, 57: 1-35.

Instituto Brasileiro de Geografia e Estatística (IBGE). 1978. Mapa de clima do Brasil. Available at: https://www.ibge.gov.br/geociencias/informacoesambientais/climatologia/15817-clima.html@?=\&t=downloads. Access in: 05/01/2020.

Instituto Brasileiro de Geografia e Estatística (IBGE). 2004a. Mapa de biomas do Brasil. Available at: ftp://ftp.ibge.gov.br/Cartas e Mapas/Mapas Murais. Access in: 12/11/2018.

Instituto Brasileiro de Geografia e Estatística (IBGE). 2004b. Mapa de vegetação do Brasil. Available at: ftp://geoftp.ibge.gov.br/informacoes ambientais/vegetacao/mapas/brasil/vegetacao.pdf. Access in: 07/24/2019.

Instituto Chico Mendes de Conservação da Biodiversidade (ICMBio). 2018. Livro vermelho da fauna brasileira ameaçada de extinção. Mamíferos. Brasília, ICMBio/MMA. v. 2.

International Union for Conservation of Nature and Natural Resources (IUCN). 2019. The IUCN Red List of Threatened Species. Version 2019-1. Available at: http://www.iucnredlist.org. Access in: 03/21/2019.

Langguth, A. 1963. Las especies uruguayas del genero Oryzomys (Rodentia, (ricetidae). Comunicaciones Zoológicas del Museo de Historia Natural de Montevideo, 7: 1-19.

Leite, P.F. 2002. Contribuição ao conhecimento fitoecológico do sul do Brasil. Ciência e Ambiente, 24: 51-73.

Lemos, H.M.; Silva, C.A.O.; Patiu, F.M. \& Gonçalves, P.R. 2015. Barn owl pellets (Aves: Tyto furcata) reveal a higher mammalian richness in the Restinga de Jurubatiba National Park, Southeastern Brazil. Biota Neotropica, 15(2): e20140121.

Lima, D.0.; Azambuja, B.0.; Camilotti, V.L. \& Cáceres, N.C. 2010. Small mammal community structure and microhabitat use in the austral boundary of the Atlantic Forest, Brazil. Zoologia, 27(1): 99-105.

Luza, A.L.; Gonçalves, G.L.; Pillar, V.D. \& Hartz, S.M. 2016. Processes related to habitat selection, diversity and niche similarity in assemblages of non-volant small mammals at grassland-forest ecotones. Natureza e Conservação, 14(2): 88-98.

Machado, F.S.; Lima, I.J.; Lopes, A.P.M.; Moura, A.S. \& Abreu, T.C.K. 2016. New occurrences and biological aspects to four species of rodents (Mammalia: (ricetidae) from Brazil. Revista Agrogeoambiental, 8(2): 35-51.

Machado, L.F.; Paresque, R. \& Christoff, A.U. 2011. Anatomia comparada e morfometria de Oligoryzomys nigripes e 0 . flavescens (Rodentia, 
Sigmodontinae) no Rio Grande do Sul, Brasil. Papeis Avulsos de Zoologia, 51(3): 29-47.

Machado, L.F.; Passaia, M.H; Rodrigues, F.P.; Peters, F.B.; Sponchiado, J.; Valiati, V.H. \& Christoff, A.U. 2015. Molecular phylogenetic position of endangered Wilfredomys within Sigmodontinae (Cricetidae) based on mitochondrial and nuclear DNA sequences and comments on Wiedomyini. Zootaxa, 3986(4): 421-434.

Mancini, M.C.S.; Roth, P.R.0.; Brennand, P.G.G.; Aguilar, J.M.R.E. \& Rocha, P.A. 2018. Tyto furcata (Tytonidae: Strigiformes) pellets: tools to access the richness of small mammals of a poorly known Caatinga area in northeast Brazil. Mammalia, 83(4): 390-398.

Massoia, E.; Chébez, J.C. \& Fortabat, S.H. 1990. Mamíferos depredados por Tyto alba tuidara en Desaguadero, departamento capital, provincia de Corrientes. Boletín Científico APRONA, 18: 14-17.

Meek, W.R.; Burman, P.J.; Sparks, T.H.; Nowakowski, M. \& Burman, N.J. 2012. The use of barn owl Tyto alba pellets to assess population change in small mammals. Bird Study, 59(2): 66-174.

Melo, G.; Sponchiado, J.; Machado, A. \& Cáceres, N. 2011. Small-mammal community structure in a South American deciduous Atlantic Forest. Community Ecology, 12(1): 58-66.

Ministério do Meio Ambiente (MMA). 1992. Shapefile do mapa de vegetação do Brasil. Available at: http://mapas.mma.gov.br/i3geo/datadowload. htm. Access in: 04/17/2018.

Morrone, J.J. 2001. Biogeografia de América Latina y el Caribe. Zaragoza, M\&T. 148p. (Manuales \& Tesis SEA, 3).

Oliveira, J.A. \& Gonçalves, P.R. 2015. Genus Oxymycterus Waterhouse, 1837. In: Patton, J.L.; Pardiñas, U.F.J. \& D'Elía, G. (Eds.). Mammals of South America. Chicago, The University of Chicago Press. Vol. 2, p. 247-268.

Overbeck, G.E.; Vélez-Martin, E.; Scarano, F.R.; Lewinsohn, T.M.; Fonseca, C.R.; Meyer, S.T.; Müller, S.C.; Ceotto, P.; Dadalt, L.; Durigan, G.; Ganade, G.; Gossner, M.M.; Guadagnin, D.L.; Lorenzen, K.; Jacobi, C.M.; Weisser, W.W. \& Pillar, V.D. 2015. Conservation in Brazil needs to include non-forest ecosystems. Diversity and Distributions, 21: 1455-1460.

Paglia, A.P.; Fonseca, G.A.B.; Rylands, A.B.; Herrmann, G.; Aguiar, L.M.S.; Chiarello, A.G.; Leite, Y.L.R.; Costa, L.P.; Siciliano, S.; Kierulff, M.C.M.; Mendes, S.; Tavares, V.; Tavares, C.; Mittermeier, R. \& Patton, J.L. 2012. Lista anotada dos mamiferos do Brasil/Annotated checklist of Brazilian mammals. 2. ed. Arlington, Conservation International. 83p. (0ccasional Papers in Conservation Biology, n. 6).

Paise, G. \& Vieira, E.M. 2006. Daily activity of a Neotropical rodent (Oxymycterus nasutus): seasonal changes and influence of environmental factor. Journal of Mammalogy, 87(4): 733-739.

Pardiñas, U.F.J. \& Teta, P. 2011. Fossil history of the marsh rats of the genus Holochilus and Lundomys (Cricetidae, Sigmodontinae) in southern South America. Estudios Geológicos, 67(1): 111-129.

Pardiñas, U.F.J. \& Teta, P. 2013. Taxonomic status of Mus talpinus Lund (Rodentia: Sigmodontinae) from the Quaternary deposits of Lagoa Santa, Minas Gerais, Brazil and its paleoenvironmental meaning. Mammalia, 77(3): 347-355.

Pardiñas, U.F.J.; D'Elía, G. \& Teta, P. 2015a. Genus Bibimys Massoia, 1979. In: Patton, J.L.; Pardiñas, U.F.J. \& D'Elía, G. (Eds.). Mammals of South America. The Chicago, University of Chicago Press. v. 2, p. 204-208.

Pardiñas, U.F.J.; Myers, P.; León-Paniagua, L.; Garza, N.0.; Cook, J.; Kryštufek, B.; Haslauer, R.; Bradley, R.; Shenbrot, G. \& Patton, J.L. 2017b. Family Cricetidae. In: Wilson, D.E.; Lacher, T.E. \& Mittermeier, R.A. (Eds.). Handbook of the mammals of the world. Vol. 7, Rodents II. Barcelona, Lynx Edicions. p. 204-279.

Pardiñas, U.F.J.; Teta, P. \& Forbatat, S.H. 2005. Vertebrate prey of the barn owl (Tyto alba) in subtropical wetlands of northeastern Argentina and eastern Paraguay. Journal of Raptor Research, 39(1): 65-69.
Pardiñas, U.F.J.; Teta, P.; Alvarado-Serrano, D.; Geise, L.; Jayat, J.P.; Ortiz, P.E.; Gonçalves, P.R. \& D'Elía, G. 2015b. Genus Akodon Meyen, 1833. In: Patton, J.L.; Pardiñas, U.F.J. \& D'Elía, G. (Eds.). Mammals of South America. The Chicago, University of Chicago Press. v. 2, p. 144-204.

Pardiñas, U.F.J.; Teta, P.; D'Elía, G. \& Galliari, C. 2008. Rediscovery of Juliomys pictipes (Rodentia: Cricetidae) in Argentina: emended diagnosis, geographic distribution, and insights on genetic structure. Zootaxa, 1758: 29-44.

Pardiñas, U.F.J.; Teta, P.; Voglino, D. \& Fernández, F.J. 2013. Enlarging rodent diversity in west-central Argentina: a new species of the genus Holochilus (Cricetidae, Sigmodontinae). Journal of Mammalogy, 94(1): 231-240.

Pardiñas, U.F.J.; Voglino, D. \& Galliari, C.A. 2017a. Miscellany on Bibimys (Rodentia, Sigmodontinae), a unique akodontine cricetid. Mastozoología Neotropical, 24(1): 241-250.

Pardini, R. \& Umetsu, F. 2006. Pequenos mamíferos não-voadores da Reserva Florestal do Morro Grande - distribuição das espécies e da diversidade em uma área de Mata Atlântica. Biota Neotropica, 6(2): 1-22.

Patton, J.L.; Pardinãs, U.F.J. \& D'Elía, G. (Eds.). 2015. Mammals of South America. The Chicago, University of Chicago Press. v. 2.

Pavan, S.E. \& Leite, Y.L.R. 2011. Morphological diagnosis and geographic distribution of Atlantic Forest red-rumped mice of the genus Juliomys (Rodentia: Sigmodontinae). Zoologia, 28(5): 663-672.

Peters, F.B.; Roth, P.R.O.; Machado, L.F.; Coelho, E.L.; Jung, D.M.H. \& Christoff, A.U. 2010. Assembléia de mamíferos dos agroecossistemas constituintes da bacia hidrográfica do rio da Várzea, Rio Grande do Sul. Biotemas, 23(4): 91-107.

Pine, R.H. 1980. Notes on rodents of the genera Wiedomys and Thomasomys (including Wilfredomys). Mammalia, 44(2): 195-202.

Pires, L.; Leite, Y.L.R.; Fonseca, G. \& Tavares de Fonseca, M. 2000. Biogeography of South American Forest Mammals: endemism and diversity in the Atlantic Forest. Biotropica, 32(4): 872-881.

Quintela, F.M.; Silveira, E.C.; Dellagnese, D.G. \& Cademartori, C.V. 2014. Calomys tener (Winge, 1887) (Rodentia: Cricetidae: Sigmodontinae): Filling gaps. Check List, 10(3): 650-654.

Rio Grande do Sul. 2013. Portaria SEMA № 79, de 31 de outubro de 2013. Available at: https://www.legisweb.com.br/legislacao/?id=261368. Access in: 07/18/2017.

Rio Grande do Sul. 2014. Decreto № 51.797, de 8 de setembro de 2014. Diário oficial.

Rocha, R.G.; Justino, J.; Leite, Y.L.R.; Fonseca, C. \& Costa, L.P. 2015. DNA from owl pellet bones uncovers hidden biodiversity. Systematics and Biodiversity, 13(4): 403-412.

Salazar-Bravo, J. 2015. Genus Calomys Waterhouse, 1837. In: Patton, J.L.; Pardiñas, U.F.J. \& D'Elía, G. (Eds.). Mammals of South America. Vol. 2. Chicago, The University of Chicago Press. p. 481-507.

Scheibler, D.R. \& Christoff, A.U. 2007. Habitat associations of small mammals in southern Brazil and use of regurgitated pellets of birds of prey for inventorying a local fauna. Brazilian Journal of Biology, 67(4): 619-625.

Silveira, E.C.; Cadermatori, C.V. \& Kautzmann, R.M. 2011. Avaliação de indicadores ambientais em área úmida na APA do Banhado Grande, Viamão, RS, para uso em processos de mitigação e restauração ambiental. In: Congresso Brasileiro de Carvão Mineral, 3]. Anais. Porto Alegre, Universidade Federal do Rio Grande do Sul.

Sponchiado, J.; Melo, G.L. \& Cáceres, N.C. 2012. Habitat selection by small mammals in Brazilian Pampas biome. Journal of Natural History, 46(21-22): 1321-1335

Stutz, N.S.; Cherem, J.J.; Pardiñas, U.F.J. \& Hadler, P. 2017. Roedores sigmodontíneos (Mammalia, Rodentia, Cricetidae) holocênicos do Rio Grande do Sul, Brasil - 0 sítio RS-TQ-58: Afonso Garivaldino Rodrigues. Revista Brasileira de Paleontologia, 20(1): 133-148. 
Stutz, N.S.; Hadler, P.; Cherem, J.J.; Fernández, F.J.; Pardiñas, U.F.J. \& Ribeiro, A.M. 2018. Noteworthy sigmodontine (Rodentia: Cricetidae) diversity in southern Brazil as an indication of environmental change during the Holocene. Historical Biology: A, International Journal of Paleobiology, 30: 1-22. https://www.tandfonline.com/doi/full/10.1080/08912963.2018. 1524470.

Taylor, I. 1994. Barn Owls. Predator-prey relationships and conservation. Cambridge, Cambridge University Press.

Teta, P.; González-Fischer, C.M.; Codesido, M. \& Bilenca, D.N. 2010. A contribution from barn owl pellets analysis to known micromammalian distributions in Buenos Aires province, Argentina. Mammalia, 74(1): 97-103.

Thomas, 0. 1928. A new Thomasomys from Rio Grande do Sul. Annals \& Magazine of Natural History, 10(2): 409-410.
Torre, I.; Arrizabalaga, A. \& Carles, F. 2004. Three methods for assessing richness and composition of small mammal communities. Journal of Mammalogy, 85(3): 524-530.

Vaz Ferreira, R. 1960. Nota sobre Cricetinae del Uruguay. Archivos de la Sociedad de Biología de Montevideo, 24: 66-75.

Voss, R.S. 2015. Genus Lundomys Voss and Carleton, 1993. In: Patton, J.L.; Pardiñas, U.F.J. \& D'Elía, G. (Eds.). Mammals of South America. Chicago, The University of Chicago Press. v. 2, p. 346-348.

Voss, R.S. \& Carleton, M.D. 1993. A new genus for Hesperomys molitor Winge and Holochilus magnus Hershkovitz (Rodentia; Muridea) with an analysis of its phylogenetic relationships. American Museum Novitates, 3085: 1-39.

Wilson, D.E. \& Reeder, D.M. (Eds.). 2005. Mammal species of the world: a taxonomic and geographic reference. 3. ed. Baltimore, The Johns Hopkins University Press.

\section{APPENDIX 1}

List of the specimens deposited in the Coleção de Mamíferos do Departamento de Ecologia e Zoologia da Universidade Federal de Santa Catarina (UFSC) which were used for comparison with the SLS owl pellet specimens:

Cryptonanus guahybae: UFSC 4465, 4589, 4854, 5197, 5234, 5434. Gracilinanus microtarsus: UFSC 3851, 4857, 5951, 5893. Marmosa paraguayana: UFSC 4048, 4374. Monodelphis dimidiata: UFSC 3778, 4823, 4861, 5740. Monodelphis iheringi: UFSC 3797, 4585, 4607, 5436. Monodelphis scalops: UFSC 3780, 3915, 4056. Akodon montensis: UFSC 222, 288. Akodon paranaensis: UFSC 3628, 3631. Brucepattersonius iheringi: UFSC 3425, 4925. Brucepattersonius soricinus: UFSC 4692, 4810. Calomys tener: UFSC 5166, 5490. Euryoryzomys russatus: UFSC 4960, 4961. Juliomys ossitenuis: UFSC 950, 4812. Juliomys pictipes: UFSC 2960, 2963. Necromys lasiurus: UFSC 3599, 3600, 3876, 4714. Nectomys squamipes: UFSC 5078, 5494. Oligoryzomys flavescens: UFSC 3643, 4400, 4548, 4694. Oligoryzomys nigripes: UFSC 498, 501, 3638, 4544. Oxymycterus dasythrichus: UFSC 2084, 2085, 2086. Oxymycterus nasutus: UFSC 955, 5892, 5934. Oxymycterus quaestor: UFSC 4817, 5645, 5787. Scapteromys meridionalis: UFSC 2662, 2671, 3597, 3819. Sooretamys angouya: UFSC 5927, 6031. Rattus norvegicus: UFSC 428, 5456. Rattus rattus: UFSC 5565, 5749. 


\title{
Erratum
}

In the article "Small mammal diversity in Semi-deciduous Seasonal Forest of the southernmost Brazilian Pampa: the importance of owl pellets for rapid inventories in human-changing ecosystems", http://doi.org/10.11606/1807-0205/2020.60.25, published in the Journal Papéis Avulsos de Zoologia, Volume 60: 1-12, the material attributed to Nectomys squamipes was misidentified. The material in fact is quite large specimens of Sooretamys angouya. So,

\author{
In the Abstract: \\ Where you read: \\ ... individuals belonging to 19 taxa were recorded, \\ Read it: \\ ... individuals belonging to 18 taxa were recorded, \\ Where you read: \\ ... and 15 rodents (Cricetidae, Muridae, Caviidae; 99.46\%). \\ Read it: \\ ... and 14 rodents (Cricetidae, Muridae, Caviidae; 99.46\%).
}

\section{In page 3:}

\section{Where you read:}

... 2,617 individuals belonging to 19 small mammal taxa, including two didelphimorphian species (Didelphidae) (Fig. 2), two chiropterans (Molossidae and Phyllostomidae) (Fig. 3), and 15 rodents (Cricetidae, Muridae, and Caviidae)...

\section{Read it:}

... 2,617 individuals belonging to 18 small mammal taxa, including two didelphimorphian species (Didelphidae) (Fig. 2), two chiropterans (Molossidae and Phyllostomidae) (Fig. 3), and 14 rodents (Cricetidae, Muridae, and (aviidae)...

\section{In page 5:}

\section{Where you read:}

The other 12 taxa together represented $5.46 \%$ of the individuals.

Read it:

The other 14 taxa together represented $5.51 \%$ of the individuals.

\section{Where you read:}

(G) = Nectomys squamipes, UFSC-CF 32-10-1, right m1-m3.

Read it:

(G) = Sooretamys angouya, UFSC-CF 32-10-1, right m1-m3.

\section{In page 6:}

\section{The correct Table 2 is shown below:}

Pap. Avulsos Zool., 2020; v.60: e20206038

http://doi.org/10.11606/1807-0205/2020.60.38

http://www.revistas.usp.br/paz

http://www.scielo.br/paz

Edited by: Carlos José Einicker Lamas

Received: 22/06/2020

Accepted: 22/06/2020

Published: 16/07/2020
ISSN On-Line: 1807-0205

ISSN Printed: 0031-1049

ISNI: 0000-0004-0384-1825 
Table 2. Minimum number of individuals per taxon of small mammals registered in Tyto furcata pellets from the municipality of São Lourenço do Sul, State of Rio Grande do Sul, Brazil. The sites abbreviations follow Table 1.

\begin{tabular}{|c|c|c|c|c|c|c|c|c|c|c|c|c|c|c|}
\hline Taxon & BV1 & BV2 & BOQ & CGA & EV1 & EV2 & ANT & PF1 & PF2 & QV1 & QV2 & RES & Total & $\%$ \\
\hline \multicolumn{15}{|l|}{ Didelphimorphia } \\
\hline \multicolumn{15}{|l|}{ Didelphidae } \\
\hline Cryptonanus guahybae (Tate, 1931) & & & 1 & & & 1 & & 7 & & & & & 9 & 0,34 \\
\hline Gracilinanus microtarsus (Wagner, 1842) & & & & & & 1 & & 1 & & & & & 2 & 0,08 \\
\hline \multicolumn{15}{|l|}{ Chiroptera } \\
\hline \multicolumn{15}{|l|}{ Molossidae } \\
\hline Tadarida brasiliensis (I. Geoffroy, 1824) & & & & & & 1 & & & & & & & 1 & 0,04 \\
\hline \multicolumn{15}{|l|}{ Phyllostomidae } \\
\hline Sturnira lilium (E. Geoffroy, 1810) & & & & & 2 & & & & & & & & 2 & 0,08 \\
\hline \multicolumn{15}{|l|}{ Rodentia } \\
\hline \multicolumn{15}{|l|}{ Cricetidae } \\
\hline Akodon azarae (J. Fischer, 1829) & & & & & & & & & & & 3 & & 3 & 0,11 \\
\hline Akodon spp. & 9 & 4 & 9 & 2 & 4 & 15 & 2 & 104 & 4 & 3 & 3 & & 159 & 6,07 \\
\hline Bibimys sp. & & & & & & 2 & & 10 & 1 & & & & 13 & 0,50 \\
\hline Calomys sp. & 5 & 5 & 3 & 5 & 13 & 21 & 10 & 122 & 3 & 3 & 10 & & 200 & 7,64 \\
\hline Juliomys sp. & & & & & & & & 1 & & & & & 1 & 0,04 \\
\hline Holochilus sp. & & & 1 & & & & & 3 & & & 3 & & 7 & 0,27 \\
\hline Lundomys molitor (Winge, 1887) & & & & & & & & 1 & & & & & 1 & 0,04 \\
\hline Oligoryzomys sp. & 41 & 21 & 42 & 26 & 26 & 145 & 23 & 949 & 38 & 13 & 50 & & 1374 & 52,5 \\
\hline Oxymycterus nasutus (Waterhouse, 1837) & 1 & 1 & 4 & 1 & & 4 & 3 & 51 & & & 8 & 1 & 74 & 2,82 \\
\hline Sooretamys angouya (G. Fischer, 1814) & & 1 & 1 & 1 & & 1 & 1 & 4 & & & & 2 & 11 & 0,42 \\
\hline Wilfredomys oenax (Thomas, 1928) & & & & & & 3 & & 7 & & 1 & & & 11 & 0,42 \\
\hline \multicolumn{15}{|l|}{ Muridae } \\
\hline Mus musculus Linnaeus, 1758 & 15 & 20 & 32 & 4 & 9 & 22 & 33 & 564 & 12 & 2 & 26 & 1 & 740 & 28,28 \\
\hline Rattus rattus (Linnaeus, 1758) & & & 2 & & & & & 5 & & & & & 7 & 0,27 \\
\hline \multicolumn{15}{|l|}{ Caviidae } \\
\hline Cavia aperea Erxleben, 1777 & & & & & & & & 1 & & & 1 & & 2 & 0,08 \\
\hline MNI & 71 & 52 & 95 & 39 & 54 & 216 & 72 & 1830 & 58 & 22 & 104 & 4 & 2617 & 100,00 \\
\hline Richness (small mammals total) & 5 & 6 & 9 & 6 & 5 & 11 & 6 & 15 & 5 & 5 & 8 & 3 & 18 & \\
\hline
\end{tabular}

\section{In page 8:}

\section{Where you read:}

... (Juliomys, Nectomys, Sooretasmys).

Read it:

... (Juliomys, Sooretamys).

\section{Where you read:}

Corroborating this, Juliomys sp., Nectomys squamipes, and Sooretamys angouya,

Read it:

Corroborating this, Juliomys sp., and Sooretamys angouya,

\section{Where you read:}

... (Paglia et al., 2012), while N. squamipes, a semiaquatic rodent, is strongly associated with this biome and the adjacent Cerrado gallery forests (Bonvicino \& Weksler, 2015).

Read it:

... (Paglia et al., 2012).

\section{In page 9:}

Where you read:

... including at least 17 taxa of non-volant small mammals...

Read it:

... including at least 16 taxa of non-volant small mammals... 